\title{
O Programa de Educação Pelo Trabalho para a Saúde -Pet-Saúde e Humanização: Caminhos para uma Formação Interdisciplinar no Âmbito da Saúde Materna
}

\author{
Barakat, Roberta Duarte Maia \\ Universidade de Fortaleza - Unifor — robertadumaia@gmail.com
}

INTRODUÇÃO: Os atuais cenários do processo ensino-aprendizagem contemplam práticas interdisciplinares e a adoção de metodologias ativas, objetivando a qualidade nas futuras gerações de profissionais de saúde em diferentes áreas. o Programa de Educação pelo Trabalho para a Saúde (PET-Saúde) configura-se como uma estratégia que possibilita essa integração, revelandose uma ferramenta eficaz de fomento à humanização. Isso possibilita maior contato com a realidade do SUS e estimula o aprendizado multiprofissional para uma prática mais humanista e reflexiva. OBJETIVOS: Relatar atividades do processo de ensino-aprendizagem da preceptoria do PETSaúde como potencial qualificador no aprendizado interdisciplinar e humanizado do cuidado no âmbito da Saúde Materna. MÉTODOS: Relato de Experiência em um ano de atuação dos monitores do PET-Saúde, dos cursos de enfermagem, medicina, odontologia, educação física, farmácia, nutrição, fisioterapia e fonoaudiologia no atendimento às gestantes e puérperas em uma Unidade Básica de Saúde. Os monitores e sua preceptora, uma assistente social, realizaram atividades de: Orientação e acompanhamento às consultas de pré-natal e puericultura; Participação ativa na elaboração, mobilização e condução de oficinas para gestantes; Participação ativa em visitas domiciliares às puérperas; Participação ativa em oficinas de aleitamento materno para gestantes e puérperas; Realização de educação em saúde nas salas de espera com temáticas direcionadas à humanização e acolhimento às gestantes; Orientação e acompanhamento às gestantes em visitas realizadas à maternidade referenciada pelo território. RESULTADOS: Os monitores referem incorporar com êxito a práxis do olhar humanizado no fazer profissional, o que sedimenta a melhoria do aprendizado e a evolução das ações interdisciplinares, inclusive o fortalecimento do vínculo alunos-usuárias. o exercício das ações interdisciplinares nas atividades de prevenção e educação em saúde favorecem o aprendizado e a capacidade de lidar com os diferentes olhares, seja na conscientização ou na compreensão de que todos contribuem para o saber. Sob o olhar da preceptora, observou-se maior habilidade na conceituação de processos das metodologias-ativas, ampliando a visão da importância grandiosa do trabalho humanizado e multidisciplinar. CONCLUSÕES: o envolvimento e a integração de potenciais humanos participando ativamente na proposta de conhecer a realidade mediante a prática humanística são gratificantes, ao passo que se percebe a identificação dos alunos com a promoção do cuidado do fazer profissional. Percebemos que estas ações inferem positivamente no processo formativo profissional e pessoal, além de promover a integração ensino-serviço-comunidade, e consequentemente resultando na promoção da qualidade dos serviços de saúde.

Barakat, Roberta Duarte Maia. O Programa de Educação Pelo Trabalho para a Saúde -Pet-Saúde e Humanização: Caminhos para uma Formação Interdisciplinar no Âmbito da Saúde Materna. In: Anais do Congresso Internacional de Humanidades \& Humanização em Saúde [= Blucher Medical Proceedings, num.2, vol.1]. São Paulo: Editora Blucher, 2014. ISSN 2357-7282

DOI 10.5151/medpro-cihhs-10772 